al-Ihkam: Jurnal Hukum dan Pranata Sosial, 15 (1), 2020: 31-49

ISSN: 1907-591X, E-ISSN: 2442-3084

DOI: http://doi.org/10.19105/al-ihkam.v15i1.2250

\title{
Legal Protection for Disputing Parties Through the Aceh Customary Court
}

\author{
Dahlia Darida \\ Universitas Syiah Kuala, Jl. Teuku Nyak Arif, Kota Banda Aceh, Aceh 23111 \\ Email: dahliafaridash@yahoo.com \\ Hamid Sarong \\ Universitas Syiah Kuala, Jl. Teuku Nyak Arif, Kota Banda Aceh, Aceh 23111 \\ Darmawan \\ Universitas Syiah Kuala, Jl. Teuku Nyak Arif, Kota Banda Aceh, Aceh 23111 \\ Fitriah M. Suud \\ Universitas Muhammadiyah Yogyakarta, Jl. Brawijaya, Geblagan, Tamantirto, Kec. \\ Kasihan, Bantul, Daerah Istimewa Yogyakarta 55183 \\ Article history: Received: 27 April 2019, Accepted: 29 September 2019, Published: 27 Juni 2020
}

\begin{abstract}
:
Article 13 paragraph (1) of the Aceh Qanun Number 9 of 2008 on the Development of Customary and Indigenous Life discussing customary disputes mentions that ideally, the customary court can solve customary disputes. However, sometimes, it can not solve all cases and provide legal protection for all disputing parties. This study aims to explain the process of resolving private disputes through the customary court and providing legal protection for the parties. This type of research was empirical juridical with qualitative analysis. The results showed that a dispute resolution process could be done through two models. First is through customary judicature using formalized procedures by involving customary instruments. Second is using positive law indicator by not providing legal protection for the parties. Certain parties will typically file a lawsuit again after getting the customary court's decision. This research suggests collaboration among the Government, the Police, and the Customary Assembly in consistently promoting the customary court and improving the quality of customary instruments.
\end{abstract}

Author correspondence email: dahliafaridash@yahoo.com Available online at: http://ejournal.iainmadura.ac.id/index.php/alihkam/ Copyright (c) 2020 by al-ihkam. All Right Reserved 


\title{
Keywords:
}

Legal Protection; Dispute Resolution; Customary Court; Aceh

\begin{abstract}
Abstrak:
Pasal 13 ayat (1) Qanun Aceh Nomor 9 Tahun 2008 tentang Pembinaan Kehidupan Adat dan Adat Istiadat menegaskan bahwa idealnya, berbagai sengketa adat dapat diselesaikan melalui peradilan adat. Namun demikian faktanya, tidak semua kasus dapat diselesaikan dengan baik pun tidak semua pihak mendapat perlindungan hukum. Penelitian ini bertujuan menjelaskan proses penyelesaian sengketa perdata melalui peradilan adat dan perlindungan hukum bagi para pihak. Jenis penelitian ini adalah yuridis empiris dengan analisis kualitatif. Hasil penelitian menunjukkan proses penyelesaian sengketa dilakukan melalui dua model. Pertama adalah peradilan adat dengan prosedur yang telah diformalkan atau proses yang hanya melibatkan perangkat desa. Kedua adalah menggunakan indikator hukum positif dengan tidak memberikan perlindungan hukum para pihak terkait. Pihak-pihak tertentu biasanya akan mengajukan gugatan kembali setelah pembacaan putusan peradilan adat. Penelitian ini menyarankan adanya kerjasama berkelanjutan antara Pemerintah, Kepolisian, dan Majelis Adat dalam mensosialisasikan peradilan adat secara konsisten serta memberikan peningkatan kapasitas bagi perangkat adat.
\end{abstract}

\section{Kata Kunci:}

Perlindungan Hukum; Penyelesaian Sengketa;

Peradilan Adat; Aceh

\section{Introduction}

Throughout the history, the practice of customary law aims to ensure that all problems in society can get complete solution. Customary law resolves them thoroughly and answers all existing aspects or those may exist so that in the future, there will be no more unsolved similar problems. Related to this, Koesno stated that there are no problems that cannot be solved. For him, furthermore, 
customary law aims to achieve safe, prosperous and peaceful society both between the engaging parties and community as a whole."1

From the point of view of its purpose, customary law is different from positive law. Positive law aims to provide legal certainty, while customary law is to restore balance in society. Based on this, responsive type of law is all that people need because it emphasis on legal objectives based on legal substance. It also puts the law as a response of social needs and public aspirations. In accordance to its open character, this type of law prioritizes accommodation to accept social changes ${ }^{2}$ while the orthodox community tend to bring up forced customary laws (repressive). The repressive type of law aims to achieve order and obedience in maintaining the existence of the state, whereas autonomous law aims for oriented legitimation which adheres strictly to legal procedures. ${ }^{3}$

The concept of customary peace had existed before Islam particularly at the fifth year before Muhammad's prophety. It was the event of Hajar al-Aswad seizure after it was moved from its original place when the flood attacked Mecca. All leaders of Quraysh tribes scrambled to get right for putting back the Hajar al-Aswad and each of tribal chiefs felt that they deserved more than others. It is believed that Hajar al-Aswad is a gemstone whiter than snow sent down by Allah from the sky but it became black because of humans' sins or crimes. 4

The peace agreement for the complicated problem was initiated by the first person who entered the Ka'bah. He was Muhammad bin Abdullah who had the title of Muhammad Al-Amin (the trustworthy Muhammad). He resolved the problem wisely by removing the turban that covered his head then opened it in front of the Ka'bah. Later, he put Hajar al-Aswad on the center of turban and

\footnotetext{
${ }_{1}$ Moh Koesno, Hukum Adat sebagai Suatu Model Hukum Historis, (Bandung: Mandar Maju, 2002), 11.

2Mohammad Jamin, Peradilan Adat, Pergeseran Politik Hukum Perspektif Undang-Undang Otonomi Khusus Papua. (Yogyakarta: Graha Ilmu, 2012),. 24-25.

3Siswantoro Sunarso, Penegakan Hukum Psikotropika dalam Kajian Sosiologi Hukum, (Jakarta: Raja Grafindo Persada, 2004),. 85.

4Yani Suryani, et al, Tempat Bersejarah Umat Islam, (Jakarta: Luxima Metro Media, 2014), 35.
} 
asked representatives of each tribe to hold the edges of the turban and put the stone back at the first place on Al-aswad. ${ }^{5}$

This event proved that peace which can solve problems in society is something that people can seek for. It also made it clear about Arabic tradition at that time in which Arabians were charismatic, held high position or were able to solve problems they coped with. Muhammad bin Abdullah was a charismatic person among the Jahiliyah Arabs before he became a prophet and was much highly respected by his companions, scholars, to traditional leaders.

Relating to this, nowadays in Indonesia, the province of Aceh is a special regional government. What makes it special is its customs and law which are blended with implementation of Islamic law and culture. In the field of law, Aceh applies the implementation of sharia law (Islamic law) and customary law which is relatively different from other regions in Indonesia. Customary law itself is a role model and an implementation of attitude or character (geist) of daily practices in society that is more ethnical or based on community groups. The characteristic and the form of customary law have traditional nuances, not written, and are sourced from their customs or habits, ${ }^{6}$ including the existence of customaty institutions.

Aceh customary institutions have their own model and approaches that have been recognized by Indonesian government as an alternative way to resolve disputes or conflicts in society. Aceh Besar District, one of the districts in Aceh, in this case, always uses customary remedies in solving social problems in the society. The customary remedies are carried out whether in formalized customary courts by following standardized mechanisms and stages of resolution or only by involving village instruments (in Aceh called Gampong) so that the engaging parties can get solution.

Based on above description, it is interesting to discuss further on the the process of private dispute resolution through the customary court in Aceh Besar District. It is the aim of this paper in

5Sumarti M. Thahir, 23 Muslimah Kesayangan Rasulullah, (Bandung: Alumni, 2002), 52.

6 Badruzzaman Ismail, Bunga Rampai Hukum Adat, (Banda Aceh: Majelis Adat Aceh, 2003),. 1. 
addition to discussion on legal protection and acceptance of the disputed parties to the customary court's decision.

\section{Research Method}

The typology of this research was empirical juridical with a qualitative approach. This approach was carried out by examining the applicable legal provisions and investigating what really happens in the community. This aims to obtain comprehensive research result as a whole related to the private dispute resolution through Aceh customary courts.

\section{The Theoretical Framework of Legal Protection and Legal Culture}

Satjipto Raharjo said that legal protection aims to protect human rights when harmed by others. The protection is given to society so that they can get all the rights granted by the law. In other words, legal protection is a variety of legal efforts that must be given by law enforcement officials to provide a sense of security both mental and physical, from disturbances and various threats. ${ }^{7}$ Relating to this, Phillipus M. Hadjon said:

"Legal protection for society is as a preventive and repressive government action. Preventive legal protection aims to prevent disputes. It directs the government to be careful in making decisions based on discretion, while repressive protection aims to resolve disputes, including handling in judicial institutions" 8

Legal protection is the protection given to the law so that it is not interpreted differently and not misused by law enforcement officers. It also means the protection provided by law against something. ${ }^{9}$ As stated by Satijipto Raharjo, a law can be used to actualize protection that is not merely adaptive and flexible, but also predictive and anticipatory. Those who are weak and not socially, economically, and politically stable need the law to obtain social justice. ${ }^{10}$

\footnotetext{
7 Satijipto Raharjo, Ilmu Hukum, (Bandung, Citra Aditya Bakti, 2000),. 74.

8Satijipto Raharjo, Ilmu Hukum, 29.

9 Sudikno Mertokusumo, Penemuan Hukum, (Bandung: Citra Aditya Bakti, 2009), 38.

10 Satijipto Raharjo, Ilmu Hukum., 55.
} 
Legal protection theory is a theory that studies and analyzes the form or purpose of protection provided by law to the subject. ${ }^{11}$ The theory of legal protection in this study shows the effectiveness of customary law in which its apparatus provides legal protection to the society. This will ultimately have an impact on the society's participation in resolving the cases they face through customary dispute resolution or participating in carrying out the customary justice.

This theory has been stated by Lawrence Meir Friedman whose theory was a part of the legal system theory. One of the subsystems in the legal system is the legal culture. Legal culture, according to Lawrence Meir Friedman, is a human attitude towards law and the legal system-beliefs, values, thoughts, and expectations. ${ }^{12}$ The legal culture here is understood as values, thoughts, and expectations of methods or norms in the social life of the community. The legal culture of society shows the atmosphere of social thought and social forces that determine how the law is used, avoided, or abused.

Talking about legal culture, Soerjono Soekanto stated that legal culture (system) is the values that underlie applicable law in the form of something that is considered good (so that it is followed) and what is considered bad (so that it is avoided). Cultural factors are one of the important factors that can influence law enforcement in addition to the law itself, law enforcement, facilities, and society. ${ }^{13}$

Legal culture, on the other hand, is closely related to public legal awareness. The higher legal awareness of the community is, the better they will create a good legal culture which can change the mindset of the society regarding the law that they have understood so far. The level of society compliance with the law becomes indicator of the law function. For example, in Acehnese society, it is well known a term called sayam as explained by Aboe Bakar in Taqwaddin Husin, et al, as follow:

11Salim HS dan Erlies Septiana Nurbani, Penerapan Teori Hukum pada Penelitian Tesis dan Disertasi, RajaGrafindo Persada, Jakarta, 2014,. 263.

${ }^{12}$ Lawrence M. Friedman, Sistem Hukum; Perspektif Ilmu Sosial (The Legal System; A Social Science Perspective), Penerjemah M. Khozim, (Bandung: Nusa Media, 2009),. 8.

13Soerjono Soekanto, Faktor-Faktor yang Mempengaruhi Penegakan Hukum, (Jakarta: Rajawali Pers, 2012),. 59-60. 
"Sayam is reconciling problems or disputes between the parties where one party or both parties are bleeding. The sanction for offenders is paying diat or fines for killing or injuring someone. The implementation of the diat among the people of Aceh is the same as the concept of the diat in Islamic criminal law (diat in Islamic shariah). There is an Acehnese expression called (hadih maja) that mentions Luka ta sipat, darah ta sukat."14

The expression above means that the wound and blood will be counted fairly so that the payment of diat will be the same as wounds or blood that comes out. The standardization is determined by the wisdom of the customary court assembly. Besides, there is an institution called suloh as an effort to resolve disputes peacefully. Suloh comes from the word Sulh in Arabic. Sulh etymologically means deciding or resolving disputes or making peace. The term was found in the figh literature relating to issues of transactions, marriage, war, and rebellion.

Terminologically, sulh is a contract determined to resolve disputes. ${ }^{15}$ It functions to reconcile disputes in society. The sanction is in the form of dam, which is the feast by slaughtering chickens, goats, cows or buffaloes. The amount and type of material for the feast depends on the level of the consequences from an offense. For minor violations, the feast in resolving the dispute through the suloh institution is enough by providing drinks, food, and yellow sticky rice. ${ }^{16}$

Forgiving one another as a community habit is a culture of obedience to the living values in society. Societies that adhere to Islamic values also recognize the system of forgiveness because of awareness that humans are not free from mistakes. At one time, a person becomes a victim of another person's crime; at other times, that

\footnotetext{
14 Taqwaddin Husin, dkk, Mukim di Aceh Belajar dari Masa Lalu untuk Pembangunan Masa Depan, (Yogyakarta: Diandra Pustaka Indonesia, 2015), 176.

${ }^{15}$ Fauzi Saleh, Konsep Suluh dan Konstruksi Pendidikan Damai di IAIN Ar-Raniry: Kontribusi Kampus dalam Dakwah Perdamaian di Aceh, (Banda Aceh: Yayasan Pena dan Ar-Raniry Press, 2007), 5.

${ }^{16}$ Agus Budi Wibowo, “Budaya Damai dalam Masyarakat Aceh," http: //agusbwaceh. blogspot. co.id/2009/08/ budaya-damai-dalam-masyarakataceh.html, (accessed on 30 April, 2018).
} 
person may be a violator or the perpetrators of crime against another person in society. Thus requires a positive contribution from customary leaders in managing their communities. Otje Salman Soemadiningrat stated that "customary law is social rules created and maintained by legal functionaries (a powerful and authoritative person) which applies and is intended to regulate legal relations in society". ${ }^{17}$

\section{The Authority of Customary Courts and Dispute Resolution}

The authority of customary instruments to resolve cases or problems in society through customary court is the attributive authority given by the set of rules as a legal basis. In connection with this, Taqwaddin Husin said:

"The rights and authority of indigenous and tribal peoples are regulated in Law Number 11 of 2006 on the Government of Aceh, Aceh Qanun Number 9 of 2008 on the Development of Customary and Indigenous Life, Aceh Qanun Number 10 of 2008 on Customary Institutions, and Governor Regulation Number 60 of 2013 on the Implementation of dispute or customary dispute resolution. They become more operational due to the Letter of Joint Governor Decree, Aceh Regional Police Head, and Aceh Customary Assembly of 2012. Therefore, on the perspective of legal and formal, Gampong as a Customary Legal Society becomes the basis of authority that is legal and authoritative."18

The source of authority of the customary legal society and the customary apparatus derives from the law. Meanwhile, the legal basis for customary instruments to carry out customary court is based on the 1945 Constitution of the Republic of Indonesia.

In particular, Article 18 B paragraph (2) of the 1945 Constitution of the Republic of Indonesia states that: "The state recognizes and respects the unity of customary law society along with their customary rights as long as they are still alive and fit with

17 Otje Salman Soemadiningrat, Rekonseptualisasi Hukum Adat Kontemporer. (Bandung: Alumni, 2002),. 14.

18Jurnal Kanun Nomor 67, Tahun XVII (Desember, 2015), Taqwaddin Husin, Penyelesaian Sengketa/Perselisihan Secara Adat Gampong di Aceh,. 511. 
society development as well as the principles of the Unitary State of Indonesia as regulated in the law."

Furthermore, Law Number 44 of 1999 on Administration of Special Privileges of the Province of Aceh in Article 3 paragraph (1) states that the privilege is an acknowledgment from the Indonesian Nation given to the regions because of the struggle and intrinsic values of the community that have been maintained for generations as spiritual, moral, and humanitarian foundation. Afterward, the Article 6 , which is the article that specifically relates to the implementation of customary life, states as follow: "Regions can establish various types of regulation in their effort to empower, preserve, and develop customs and customary institutions in their regions which are imbued and compatible to Islamic Sharia."

More specifically, Law Number 11 of 2006 on the Government of Aceh, in Article 98 Paragraph (2) states that the resolution of social problems is carried out through Customary Institutions. It is explained more at the Qanun of Nanggroe Aceh Darussalam Province Number 4 of 2003 on the wukim Government which gives mukim authority to decide and enact laws, preserve and develop local custom (adat), enforce local peace, resolve and provide customary decisions on disputes and customary violations, empower law and other reliable evidence according to custom as well as resolving based custom cases.

Additionally, Qanun of Nanggroe Aceh Darussalam Province Number 5 of 2003 on Gampong Government emphasizes that duties and obligations of the Gampong government, together with Tuha Peut and Imum Meunasah as the judge of peace, are to resolve custom disputes, keep the customary preservation, maintain order and prevent any immoral acts in the society. As for Aceh Qanun Number 9 of 2008 on the Development of Customary and Indigenous Life, particularly Article 1 Number 10 states that "custom is the rules of living conduct and habits applied in society and used as a guide to live in Aceh." Furthermore, Article 1, paragraph 11, states that Customary Law is a set of unwritten provisions that live and develop in Aceh society and as a consequence, anyone who violates it will get sanctions."

Aceh Qanun Number 10 of 2008 on Customary Institutions, in Article 1 Number 9, mentions that Customary Institution is a 
customary social organization formed by a certain customary legal society. It also has a specific territory, assets, and right as well as authority to regulate, manage, and resolve problemsor disputes relating to Acehnese customs.

In line with taht, Aceh Governor Regulation Number 25 of 2011 on General Guidelines for Administering Gampong Government, in Article 1 Number 18 states that the customary Institution is a customary social organization formed by a particular customary legal society which has its assets the right and authority to regulate, manage, and settle disputes or problems related to Acehnese customs. In addition to it, Article 5 also mentions general guidelines for the administration of Gampong government, including dispute resolution according to customary law. The Appendix of the Governor Regulation also explains that one of Tuha Peut Gampong's tasks is to resolve disputes in the society with the geuchik and customary leaders.

This traditional practice also triggers response from the local government as clear at The letter of Joint Decree of the Governor of Aceh, the Aceh Regional Police Chief, and the Chairperson of Aceh Customary Assembly Number 198/677/2011 / Number: 1054 / MAA / XII / 2011 / Number: B / 121 / I / 2012. It is on the implementation of the Gampong and Mukim Customary Courts or other related names in Aceh. Following is is a part of the official letter;

To create security, order, harmony, and peace in the society as efforts to reach prosperity and justice at Gampong and Mukim in Nanggroe Aceh Darussalam, the Customary Court Institution can function as an institution that solves customary cases or disputes as a Peace Courts institution.

This joint decree gives detail explanation as well as understanding that the disputes found at the level of Gampong and Mukim, as long as it comes from small problems as regulated in Articles 13, 14, 15 Qanun No. 9 of 2008, must be resolved in advance through the Gampong and Mukim customary courts. Any minor problems in society do not necessarily become cases to resolve legally through formal legal channels. Police officers, therefore, provide the opportunity for disputing parties to resolve the problems beforehand through Gampong or Mukim customary court.

Mentioned regulations above have provided strong foundation for carrying out customary court in Aceh. One of Aceh's 
traditional instruments is Geuchik in Gampong which has implemented and maintained customary law in resolving disputes that within the society.

A dispute or conflict is a social problem directly related to the law and therefore requires integral solution. Considering that humans are social creatures, dispute resolution must take into account and uphold human values. ${ }^{19}$ Related to private disputes in society, Article 13 paragraph (1) of the Aceh Qanun Number 9 of 2008 on the Development of Customary and Indigenous Life regulates custom disputes mention as follow.

The custom disputes includes domestic disputes, disputes in family relating to faraidh (inheritance distribution), disputes between residents, disputes over property rights, dispute over sehareukat assets, customary violations of livestock, agriculture, and forests, disputes at sea, disputes in the market, and other disputes that violate custom values.

If those mentioned disputes can be resolved by deliberation and customary 'procedure', it will provide peace and restore balance in society. This is exactly what the concept of customary court expects as its basic concept is actually the root of restorative justice. The main element of restorative justice-which is also the characteristic of customary law - sdsds is the willingness and participation of victims, perpetrators, and society in making betterment on what had happened. ${ }^{20}$

\footnotetext{
${ }^{19}$ Yuzna Zaidah, Penyelesaian Sengketa Melalui Peradilan dan Arbitrase Syari'ah di Indonesia, (Yogyakarta: Aswaja Pressindo, 2015), 3-5.

20Jurnal Kriminologi Indonesia, Vol. 6 Nomor II (Agustus 2010), Eva Achjani Zulfa, Keadilan Restoratif dan Revitalisasi Lembaga Adat di Indonesia,. 190.
} 


\section{The Process of Dispute Resolution through Customary Court}

The dispute resolution through customary court requires all parties to respect how the Gampong and Mukim customary court holds the process. In resolving the cases, the Gampong or Mukim customary court can give a verdict based on customary law norms and customs prevailing in the local area. It is clear here, therefore, that the living law in a society can be different from others.

The Gampong and Mukim customary courts process are attended by parties and witnesses. They are also open for public except for certain cases which custom and propriety consider it improper to be open. Decisions of Gampong and Mukim customary courts are final and binding. They cannot even be submitted again in general or other courts. ${ }^{21}$ Additionally, every customary court process of Gampong and Mukim was made a note in writing, signed by the chairman, members of the assembly and two disputing parties. The carbon copies of the document are delivered to the District Police Chief, Sub-District, and the Aceh Customary Assembly (MAA) in the district. ${ }^{22}$

The Gampong and Mukim Customary Court Assembly and procedures for disputes resolutions are written in Aceh Qanun No. 9 of 2008 and Aceh's Governor Regulation Number 25 of 2011 on General Guidelines for Gampong Government Administration. The administration of the Gampong and Mukim Customary Courts prohibits any decision that imposes bodily sanctions such as imprisonment, bathing with dirty water, shaving hair, cutting clothes, and other forms of sanction contrary to Islamic values. This applies for perpetrators in criminal justice process.

Meanwhile in a process of private dispute resolution, the emphasize is on the consensus agreement between disputing parties. Customary elders tend to be passive although they actually serve as mediators who are suppossed to help delivering the wishes of both parties. The customary judge, on the other hand, is prohibited to

${ }^{21}$ Responden 4, a customary elder of KeMukiman Piyeung, Interview, 22 March 2019 in Aceh Besar.

22Informant 1, the chief of Aceh Customary Board (Majelis Adat Aceh or MAA) Kabupaten Aceh Besar, Interview, 22 April 2019 in Aceh Besar. 
impose his/her will on one party or both ${ }^{23}$ because it is the disputing parties who know more about the problem-solution at hand as well as the one who will implement the verdict taken or agreed in the customary problem-solving process.

It is also important to note that cases solved at the Mukim level are what cannot be completed at the Gampong level. The Government of Aceh and Regency/City Government foster and oversee the implementation of customary Gampong and Mukim court in Aceh. The Head of Regional Police, the Chair of the MAA, and all of their staffs are also obliged to provide guidance, development, and supervision on customary law and customary court administration to ensure the compatibility to the rules and principles of customary law at the local community. In addition to it, the Government of Aceh and the Regency/City Government can help with administrative funding for the administration of the Gampong and Mukim Traditional Courts.

\section{Legal Protection and Acceptance of Disputing Parties on the Customary Court Decision}

Customary law will be well preserved when it can regulate various matters relating to society life association. In Aceh Besar, The Customary Court is engaged in solving private cases including land disputes, marriages, inheritance, and joint property (gonogini/seuhareukat assets). Serving this role, it gives legal protection for disputing parties based on customary law in order to provide peace and balance in the society. After the problem gets resolved through The Customary Court, society typically accepts both parties like before. Both are considered like people who are just born without anything to do with any problem. Everything happened in the past can be simply forgotten or ignored. ${ }^{24}$ Those parties go back to the normal life in peace. This is approperiate to what Sanusi said that the Customary Court does not recognize any justice concept and the resolution it made does not aim to find justice. Instead, when a

\footnotetext{
${ }^{23}$ Informant 2, local public figure at Aceh Besar District, Interview, 24 April 2019 in Aceh Besar.

${ }^{24}$ Responden 1, a customary elder of Gampong Ujong Keupula, Interview, 7 March 2019 in Aceh Besar.
} 
dispute gets, it intends more to restore the balance and harmony of human relations in the society. ${ }^{25}$

Meanwhile, the acceptance of disputing parties on the Customary Court decisions in civil cases in Aceh Besar Regency has two categories. First is when the parties accept it very well and second is when there found no agreement and as a consequence, the decision of customary resolution is annuled through a lawsuit/legal effort to the Court. The good acceptance at the first category above generally occurs in the type of joint property disputes such as a case between an ex-husband and wife in Gampong Empetrieng, Darul Kamal District. Whereas, the second category tends to occur in the resolution of land disputes, such as a case between residents in Meunasah Ujong Keupula in Seulimeum District, a case of a resident with Gampong Iboeh Tunong elder in Seulimeum District, and a case at Piyeung Village in Montasik District.

There also found one of parties which refused the agreement formerly made by both in the customary resolution as what occured in Lampeuneun Village, Darul Imarah District. Initially, two parties had reached an agreement in deliberations to voluntarily-without any coercion - share the disputed land object equally. However, after the decision was mentioned verbally in the peace agreement, one of the parties denied it and refused to sign the peace agreement formulated by village apparatus in the peace agreement document.

Customary society used to obey customary leaders like how they adhere to a judiciary-based deliberation and consensus-system. However, in today's society, people begin to be disobedience to customary elders and this makes it difficult for the customary law to be applied. In the past, community prioritized the public interest rather than those of individuals or groups. Nowadays, customary society does not fully trust the customary court and this leds to some annulition cases of the customary decision without considering social sanctions in the community. ${ }^{26}$ The same thing also happened in Piyeung Village, where the elders did not solve the problems as it is suppossed to be. The disputing parties wanted the elders to bring

25 Sanusi Has, Dasar-Dasar Planology, Menara: Medan, 1977,. 34.

${ }^{26}$ Responden D, a defendant on the land dispute at Gampong Lampeuneun, Darul Imarah, 14 March 2019 in Aceh Besar. 
Legal Protection for Disputing Parties

them together in order to get the problem resolved. However, The Mukim elders made a decision on the dispute in which one of the parties loses its rights as the typical decision in the general court justice. ${ }^{27}$

The customary court decision is the result of deliberation and this aims to achieve peace between two disputing parties. The meccanism of deliberation does not give any punishment. Instead, it aims to restore the situation and recover it like before as if there was no problem or dispute between parties. Meanwhile, the location in which the traditional justice process and the deliberation step takes place was generally suggested by the Customary Assembly. Otherwise, it will be decided in a deliberation forum held to consider goodness of both parties and society at general. In the Aceh customary method, it is called "adat koh rebong, koh purih law" (customary problem can be solved by deliberation, but those that have been processed by legal process must be enforced). ${ }^{28}$

In a case of joint assets, the parties accepted the decision made by the customary court in Empetrieng Village, Darul Kamal Subdistrict, Aceh Besar District sincerely and gracefully because the customary court judges did not impose the decision. Furthoremore, the decision was made by considering the parties' opinions, wishes and agreement. ${ }^{29}$ Acehnese people assume that any event, whether it was good or bad, was essentially an inevitable destiny. Therefore, each party must be grateful for all the good and bad that had happened. In the context of disputing parties, they particularly feel grateful because their opinions were respected and this makes them easy and sincere to accept customary court decision right away.

The customary court becomes an alternative solution for parties who litigate any legal problem when the general courts are often full of cases. It is also the most appropriate choice to take in settling any minor cases, especially individual ones. The customary court decision is based on deliberation of two parties in order to

27Responden C, a plaintiff on the land dispute at KeMukiman Piyeung, Interview, 22 March 2019 in Aceh Besar.

${ }^{28}$ Informant 1, the chief of Aceh Customary Board (Majelis Adat Aceh or MAA) Interview, 22 April 2019 in Aceh Besar.

${ }^{29}$ Respondent A, a plaintiff of joint assets dispute, Interview, 14 March 2019 in Aceh Besar. 
achieve justice and peace between both. When an important decision is finally reached, the parties will typically carry it out as the decision is taken consciously, freely and independently with no coercion from anyone.

Beforeward, they also agree on each stage of judicial process as they rely on the village elders to solve the problem. They fully entrust the Gampong elders to determine the whole steps to take during the process so that the defendant is finally willing to make peace with the plaintiff. Additionally, with his/her own intiative, the defendant will give the plaintiff's rights as agreed before the Gampong elders as the customary court executive. ${ }^{30}$

Both parties are considered at the same position as citizens with moral responsibilities in social life. Both are also responsible to sincerely obey the customary court's decision as they are also obliged for maintaining the decision. Moreover, before the customary court issues the decision, the parties have been actively involved in each stage of decision making so both sides can get along well like before. ${ }^{31}$

However, resolving land disputes to the general court is still important to get a legal force. This is the final step that the parties take after going through the customary court process without a decision because of different opinions. ${ }^{32}$ This attitude of the parties in resolving the case aims to resolve the problem, reconnect the 'bent' silaturrahmi (harmonious relationship), and restore balances in the society. ${ }^{33}$

There are several reasons on why Aceh Besar people chose to resolve their personal problems through customary courts. One of which is because with the customary court, they will keep maintaing a good relationship with family members so that family relationship becomes more harmonious. Another reason was the issue of the expensive cost to resolve dispute in the general court. Fifty percent of local people work as farmers and they will typically mind to pay

\footnotetext{
${ }^{30}$ Respondent B, a defendant of common property dispute, Interview, 14 March, 2019 in Aceh Besar.

${ }^{31}$ Responden 3, a customary elder of Gampong Empetrieng, Interveiw, 14 March 2019 in Aceh Besar.

32 Responden 1, a customary elder of Gampong Ujong Keupula, Intereview, 7 March 2019 in Aceh.

${ }^{33}$ Responden 2, a customary elder of Gampong Iboeh Tunong, Interview, 7 March, 2019 in Aceh Besar.
} 
Legal Protection for Disputing Parties

expensive fees that can reach up to one million rupiahs. Besides, they are also lack of understanding on how to submit cases to the court.

\section{Conclusion}

Based on discussion above, it is clear that authority of the Aceh Customary Court comes from the mandate of the Law and the Qanun (Regional Regulation) which seek to formalize customary court. Subsequently, a joint agreement was formed among the Customary Assembly, the Regional Government, and the Police to create synchronization in the implementation of customary court in resolving legal issues in the society. The process of dispute resolution through customary courts happened upon the initiative of disputing parties to resolve their problems by involving village elders. Legal protection and acceptance of disputing parties on the customary court's decision in dispute resolution are justice that restores the balance in society which was formerly disturbed due to the dispute. The parties typically accept the decision of the customary court because it fits with their wishes as well as initiative. However, it is also possible for the parties to submit legal proceedings to the general court if they feel unsatisfied with the decision of the customary court, especially in the case of property right dispute.

\section{Bibliography}

Agus Budi Wibowo, "Budaya Damai dalam Masyarakat Aceh," http:// agusbwaceh. Blogspot. co.id/2009/08/ budaya-damaidalam-masyarakat-aceh.html, (accessed on April 30, 2018).

Badruzzaman Ismail, Bunga Rampai Hukum Adat, Banda Aceh: Majelis Adat Aceh, 2003.

Bushar Muhammad. Asas-asas Hukum Adat. Jakarta: Pradnya Paramita, 2003.

Eva Achjani Zulfa, "Keadilan Restoratif dan Revitalisasi Lembaga Adat di Indonesia". Jurnal Kriminologi Indonesia, Volume. 6 Nomor II (August 2010).

Fauzi Saleh, Konsep Suluh dan Konstruksi Pendidikan Damai di IAIN ArRaniry: Kontribusi Kampus dalam Dakwah Perdamaian di Aceh, Banda Aceh: Yayasan Pena dan Ar-Raniry Press, 2007. 
Hamdany, Deny. "Cultural System of Cirebonese People: Tradition of Maulidan in the Kanoman Kraton". Indonesian Journal of Social Sciences, vol 4, no 1 (July, 2012).

Jawahir Thontowi, "Perlindungan dan Pengakuan Masyarakat Adat danTantangannya dalam Hukum Indonesia" Jurnal Hukum Ius Quia Iustum, vol. 20, no 1 (2013).

Lawrence M. Friedman, Sistem Hukum; Perspektif Ilmu Sosial(The Legal System; A Social Science Perspective), transl M. Khozim, Bandung: Nusa Media, 2009.

Mohd Koesno, Hukum Adat sebagai Suatu Model Hukum Historis, Bandung: Mandar Maju, 2002.

Mohammad Jamin, Peradilan Adat, Pergeseran Politik Hukum Perspektif Undang-Undang Otonomi Khusus Papua. Yogyakarta: Graha Ilmu, 2012.

Nurul Hakim. "Konflik Antara Al-'Urf (Hukum Adat) dan Hukum Islam Di Indonesia" in Jurnal EduTech No 2 Vol (2017): 3, http:// noorelhakim76@gmail.com. file:///C:/Users/ NOTEBOOK/Desktop/JURNAL\%20ADAT.pdf. (diakses 12 Februari 2019).

Otje Salman Soemadiningrat, Rekonseptualisasi Hukum Adat Kontemporer. Bandung: Alumni, 2002.

Salim HS dan Erlies Septiana Nurbani, Penerapan Teori Hukum pada Penelitian Tesis dan Disertasi, Jakarta: Raja Grafindo Persada, 2014.

Satijipto Raharjo, Ilmu Hukum, Bandung: Citra Aditya Bakti, 2000.

Siswantoro Sunarso, Penegakan Hukum Psikotropika dalam Kajian Sosiologi Hukum, Jakarta: Raja Grafindo Persada, 2004.

Soerjono Soekanto, Faktor-Faktor yang Mempengaruhi Penegakan Hukum, Jakarta: Rajawali Pers, 2012.

Sudikno Mertokusumo, Penemuan Hukum, Bandung: Citra Aditya Bakti, 2009.

Sumarti M. Thahir, 23 Muslimah Kesayangan Rasulullah, Bandung: Alumni, 2002. 
Legal Protection for Disputing Parties

Taqwaddin Husin, et al, Mukim di Aceh Belajar dari Masa Lalu untuk Pembangunan Masa Depan, Yogyakarta: Diandra Pustaka Indonesia, 2015.

Yani Suryani, et al, Tempat Bersejarah Umat Islam, Jakarta: Luxima Metro Media, 2014.

Yuzna Zaidah, Penyelesaian Sengketa Melalui Peradilan dan Arbitrase Syari'ah di Indonesia, Yogyakarta: Aswaja Pressindo, 2015. 